\title{
The Effect of Independent Learning Implementation in Integral Calculus Learning for the Topic Riemann Sums on Students Learning Outcomes
}

\author{
Hanifah $^{*}$ and Ahbi Mahdianing Rum
}

\author{
Department of Mathematics Education, University of Bengkulu \\ "Corresponding author. Email: hanifah@unib.ac.id
}

\begin{abstract}
The purpose of this research is to find the effect of the implementation of independent learning in integral calculus for the subject Riemann Sums on student learning outcomes in Academic Year 2020/2021. Independent Learning consists of the following stages: 1) Students access the material; 2) Discussion; 3) Collaboration; 4) Sharing Presentation. The subjects of this research were 32 students in the 3rd semester of class B mathematics education FKIP UNIB in academic year 2020/2021. The research method was the pretest, treatment, and posttest experimental method. The instrument used in this research was the pretest and posttest sheets. Student learning outcomes on the material number riemann with the concept of independent learning found that the average pretest was 41,125 while the average posttest was 62,1 . This study showed that the implementation of independent learning in integral calculus learning on the subject of the riemann number influences on student learning outcomes, with $t_{\text {count }}=30,831$ and $t_{\text {table }}=2,042$.
\end{abstract}

Keywords: Independent learning, Riemann sums, Learning outcomes.

\section{INTRODUCTION}

During the Covid-19 pandemic as it is today, it is forbidden to do direct learning in the classroom. This pandemic cannot be used as an excuse for us to stop the learning activities in school or university. It makes us more innovative in uses the existing technology to support educational activities. Even students are not allowed to come to school and university during this pandemic, but the students and teachers can still carry out the learning activities through virtual learning. Online distance learning or known as the virtual learning is carried out to break the chain of spreading Covid-19. The use of virtual learning in the process of distance learning is believed to provide ease of learning as a tool to communicate directly by virtual world. It aims to avoid physical contact in order prevent transmission of COVID-19 [1]. Online learning and direct learning are different in some aspects such as presentation, discussion, and assignation. These differences make some of the learning syntaxes that have been designed before cannot work as it should be. One case happened in integral calculus learning as one of the compulsory subjects in the Mathematics Study Program of Education Faculty of Teacher Training and
Education of Bengkulu University with 4 (3-1) credit semester. Integral calculus learning was planned to use a Learning Model Based on the Theory of Action Process Objects and Schemes (APOS Model).

APOS is a learning theory devoted to mathematics learning at the college level, which integrates computer use, learning in small groups, and takes account of mental constructions by students in understanding a mathematical concept. The Implementation of APOS model was supported by a Worksheet that contains activities for each phase, and the practicum phase was supported using maple computer applications [2]. The Worksheet consisted of activities for each phase: Orientation, Practicum, Small group discussion, Class Discussion, Exercise, or Evaluation [3]. It is a studentcentered learning model and has a syntax with phases: Orientation, Practicum, Small Group Discussion, Class Discussion, Exercise, and Evaluation [4]. The impact of the Covid-19 pandemic, which requires students to study from home, it makes the APOS Model syntax was unable to be applied according to its phase. Some (7) students do not have laptops. In addition, some students live in rural areas that far from their study partners. Based on this problem, we need to find another way so 
that students can still study optimally. We change the concept of APOS by using the concept of Independent learning. Independent Learning is a new policy program of the Ministry of Education and Culture of the Republic of Indonesia (Kemendikbud RI) which was launched by Mendikbud Nadiem Anwar Makarim. Nadiem made the policy of independent learning not without reason. The reason was based on Program for International Student Assessment (PISA) in 2019, it shows that the results of the assessment for Indonesian students place the sixth position from the bottom; for mathematics and literacy, Indonesia is the 74th position out of 79 countries. Therefore, Nadiem also made breakthroughs in assessing the minimum abilities, including literacy, numeracy, and character surveys [5].

Independent learning concepts can help the student to learn independently and develop their knowledge. According to Yamin, the concept of independent learning is an offer in reconstructing the national education system. The government is trying to restructure the education system to face the changes and progress of the nation which can adapt to changing times. It is done by restoring the true nature of education, namely education to humanize humans or education that liberates. In the concept of learning, teachers and students are subjects in the learning system. This means that the teacher is not used as a source of truth by students according to the teacher, but reall knowledge and critically the students see the world and phenomena. The opportunity for the development of the internet and technology is a momentum for freedom of learning because it can hack a rigid or non-liberating education system [6].

In learning with the concept of independent learning, the teachers and students collaborate as a driving force and seek the truth. It means that the teacher in the is not meant to instill or uniform the truth that carried out in several stages, namely accessing materials, discussions, collaboratioand presentations [7]. The concept of indepn and endent learning are a suitable concept used in the online learning period. This is because the independent learning stage allows students to prepare for learning independently at home according to the directions given by the lecturer. Sadikin and Hamidah state that online learning has the advantage of being able to foster selfregulated learning [8]. This is in line with Sun's research which states that online learning requires students to prepare their own learning, organize and evaluate and simultaneously maintain their learning motivation [9]. The concept of independent learning is needed, so the students can carry out learning in a structured, systematic manner, and get optimal results.

Students can study well using the concept of independent learning supported by existing technology today. It is in line with Pakpahan which states learning process can go well with information technology that has developed currently including e-learning, google classroom, Whatsapp, Zoom and the other media information as well as internet networks that can be connecting lecturers and students so that the teaching and learning process can going well as it should be even in of the COVID-19 pandemic [10]. Based on this information we know that, there is a lot of media information that can help students and teacher access information as much as they want. There is no reason for students, teachers, or lecturers to stop the learning process during this pandemic.

To start the learning process using the stages of independent learning, lectures take place online through the Google Classroom (GC) application. Through this application students can discuss via submissions and comment section, through this application teacher can also provide material, assignments, or quizzes using the Classwork feature. Besides using GC, students are also facilitated with materials in the form of textbooks, articles in the form of PDFs and Power Points that have been prepared and can be downloaded on e-learning of Bengkulu University. The first meeting with the topic Anti-Derivatives on September 15, 2020, began with giving a quiz. Each student gets a different question according to their respective NPM. The first quiz questions given to students are as follows:

1. Find the common anti-derivatives of the following functions:
a. $f(x)=x^{a}$
b. $f(x)=3 x^{a}+b x$
c. $f(x)=2 x^{\frac{b}{a+1}}+\sqrt{x}$

2. Determine the integral bellow.
a. $\int\left(a x^{2}+b x\right) d x$
b. $\int\left(a x^{-3}-b x^{3}+12\right) d x$
c. $\int\left(\frac{a}{b} x^{5}+b \sqrt[3]{x}\right) d x$

3. Determine the integral bellow.
a. $\int\left(2 x^{2}+3 x+a\right)^{b+1}(4 x+3) d x$
b. $\int\left(7 x^{-5}+15 x+a\right)^{b+2}\left(7 x^{-6}-3\right) d x$

$a$ and $b$ are the last two NPM numbers in a row, for example, NPM A1C019023 where $\mathrm{a}=2$ and $\mathrm{b}=3$

After being examined, the results were: $80 \%$ of students answered question number one correctly, $75.5 \%$ of students answered question number 2 correctly, and $31.67 \%$ of students answered question number 3 correctly.

The quiz questions that had been given to the students were also discussed after the quiz collection. It is intended that students know which right answers and provide them to understand about integral problems 
solutions correctly. From the discussion, it was found that students had difficulty answering question number three due to the complicated form of the questions so that students were not careful and made mistakes in making substitutions to solve question number 3 .

The second lecture with the topic Introduction to Area on September 22, 2020, again begins with a quiz consisting of the following 2 questions.

The line $\mathrm{y}=\mathrm{x}+(\mathrm{a}+\mathrm{b})$, the $\mathrm{x}$-axis, $\mathrm{x}=2$ and $\mathrm{x}=6$ ( $\mathrm{a}$ and $b$ are the last 2 numbers of NPM consecutively, for example A1C019043 then $\mathrm{a}=4$ and $\mathrm{b}=3$ )

1. Draw the inner polygon for $n=4$, then calculate the area.

2. Draw the outer polygons for $n=8$, then calculate the area.

After the quiz, the selected group presents their paper by uploading material in the GC integral class. Uploading this material is intended so that all students in the GC class understand and understand the topic at this second meeting. However, after waiting for a while, it turned out that there were no students with this material. From the results, it was known that students had difficulty in drawing graphs for polygons. This was also known from the results of the quiz which showed that only $3.125 \%$ of students answered question number 1 correctly and none of the students were able to answer question number 2 correctly. Most students made mistakes in determining graphs and determining sample points, this result in the answers obtained are still not correct.

To make students understand the correct outer polygon graph and the steps for its completion, one of the student's with correct answers was displayed on the GC, students are asked to question and answer by each other. Other questions that are still unanswered by students, then will be answered and uploaded on the GC by the assistant. As an exercise, students are given homework with the same function but for an approaching infinity. This aims to make students more understand the material about outer and inner polygons. Besides, we ask students to study or finish Integral Calculus worksheets before the third meeting is held. In the presentation phase, the Maple execution results will be displayed in zoom.

The quizzes at the first and second meetings are quizzes that given to students before the learning process in class. Quizzes are given as a tool to identify which students have understood the learning topic when studying and discussing with their group before the learning process in class begins. The quiz results at the second meeting proved that almost all students still did not understand how to draw polygon graphs and determine sample points correctly. The mistakes were made by students in answering this quiz also showed that they still did not understand the learning topic before they followed the actual learning in class. Based on the description above, a research was carried out to find out how the implementation of independent learning in integral calculus learning on the subject of the Riemann Sums affect student learning outcomes.

\section{RESEARCH METHOD}

The type of research used in this research is experimental research. This method is used to seek the effect of certain treatments on others under controlled conditions [11]. This research using The One Group Pretest-Posttest Design. This research was conducted in the 3rd semester of class B Integral Calculus of Mathematics Education, Bengkulu University. The population in this research was all students of the 3rd Semester Class B Integral Calculus class of Mathematics Education, Bengkulu University, in Academic Year 2020/2021. The research instruments used in this study were the pretest and posttest sheets.

The learning outcomes data were analyzed using the paired t-test. The hypothesis to be tested is H0: There is no effect of the implementation of independent learning on integral calculus learning for the subject Riemann Sums on student learning outcomes year 2020/2021. H1: There is an effect of the implementation of independent learning on integral calculus learning for the subject Riemann Sums on student learning outcomes year 2020/2021.

\section{RESULTS AND DISCUSSION}

\subsection{Results}

This research was done in the $3 \mathrm{~d}$ semester of Class B Integral Calculus of Mathematics Education, Bengkulu University on 15 September 2020-29 September 2020. From the results of the pretest and posttest, the following descriptions of learning outcomes were obtained:

Table 1. Descriptions of Students' Learning Outcomes

\begin{tabular}{l|l|l} 
& Pretest & Posttest \\
\hline Total Students & 32 & 32 \\
\hline Total Students' Score & 1316 & 1986 \\
\hline Average & 41,125 & 62,1 \\
\hline Lowest Score & 0 & 10 \\
\hline Highest Score & 100 & 100 \\
\hline
\end{tabular}


Student learning outcomes data in Table 1 showed that the average pretest score was 41,125 while the post-test average score was 62,1 . The highest score for the pretest and the posttest was 100 and the lowest score at the pretest was 0 and the posttest was 10 . The number of pretest was 1316 while the number of post-test scores was 1986.

After performing the $t$ test with a significance of $5 \%$ or 0.05, it was obtained that $t_{\text {count }}=30,831$ and $t_{\text {table }}=2,042$. Because $t_{\text {count }}>$ $t_{\text {table }}$, it can be concluded that there was an effect of the implementation of independent learning on integral calculus learning for the subject of Riemann Sums on student learning outcomes in Academic Year 2020/2021.

\subsection{Discussion}

The concept of independent learning consists of 4 stages, namely accessing materials, discussions, collaboration, and presentations. In the stage of accessing materials, students can access the Riemann Sums material through e-learning of Bengkulu University. Through e-learning, students were facilitated by materials in the form of textbooks, articles in the form of PDFs, and Power Points that have been prepared, and of course they can download. This material becomes material for students to discuss together with their groups before learning using GC or zoom takes place.

After accessing the material in the Unib e-learning, students would discuss it together with their group friends. Students can execute Maple syntax in the textbook using the Maple 18 application and discuss the results with their group. Through the syntax that was implemented in the Maple 18 application, students can find out the shape of the graph of the outer polygon, the inner polygon, the number of riemann, the volume of the rotating object, and so on. This will also help students understand the material to be studied during the lesson. In this discussion activity, in each group students will collaborate to share their knowledge about riemann sums according to what they have already known. Students will share each other's understanding so that the students' knowledge become more complete. Discussion method in a small group discussion can stimulate students more creative, especially in teaching and learning activities, can help them to get used to brainstorming in overcome every problem and can train students to be able to express opinions or verbal ideas, besides that discussion also can train students to respect other people's opinions [12].
The next stage was the presentation stage, this presentation stage was carried out through GC and also through zoom. Before started the learning, students were given pre-test questions to found out how far students already understand the material to be studied. Each student got a different question, this was because the questions given to students were made based on their respective NPM. The purpose of giving these different questions was to reduce the possibility of students working together in solving pre-test questions. After students complete the posttest questions, then go to the presentation stage. The presenter group displays a Power Point that contains material and examples of questions regarding the number of comments via zoom. In this presentation, it was also discussed what is the meaning of midpoint, how to determine the midpoint, the integral, and also the graph of the number of riemann. The lecture begins with giving a pretest which consists of the following questions.

The line $f(x)=2 x-a+b$, the $\mathrm{x}$-axis, the $x=1$ line and the $x=5$ line (a and $\mathrm{b}$ are the last 2 numbers of NPM respectively, for example A1C019043 then a $=4$ and $\mathrm{b}=3$ )

1. Draw and calculate the Riemann sums for the function above with the midpoint as the sample point for $\mathrm{n}=4$.

2. Calculate the Riemann sums for the function above with the midpoint as the sample point for $\mathrm{n}=$ infinity.

After the pretest, the presenter group held a web meeting using zoom. The presenter group presented integral material which was explained through a power point. During the presentation period, it was also explained how to solve the number of riemann problems using known sample points and by using the midpoint as the sample point. From the pretest results, it was found that $25 \%$ of students answered question number 1 correctly and $18.75 \%$ of students answered question number 2 correctly. The mistakes made by students, in general, determined the midpoint as the sample point as well as errors in drawing graphs. Most students draw an inner polygon graph and use the left end point as the sample point. So that what the students are doing is still not in accordance with what is ordered by the questions.

During the class discussion, students were also given practice questions regarding the sums of riemann using the midpoint as the sample point. This aimed to make students understand and trained in drawing polygon graphs. In working on the practice questions, some students were able to answer correctly. Based on this, it 
can be seen that the explanation of the material through zoom helped students understand the material sums of riemann. By using the visual and auditory messages, students can process the information quicker, which in turn, helps foster their learning acquisition of the material [13]. This can also be seen through the posttests given to students after the discussion process ends. The posttest questions were same as the pretest questions that given at the beginning of the lesson. The results of the post-test showed that, an increase in students' understanding of the riemann sums topic. It was proved by the increase in the percentage of students who answered posttest questions correctly, $25 \%$ of students were able to answer question number 1 correctly and $46.86 \%$ of students answered question number 2 correctly. The increase in student scores also can be seen from the average acquisition of student pretest and posttest scores. The average students' pretest score was 41,125 while the average post-test was 62,1 .

\section{CONCLUSION}

Based on research that has been done on students of the 3rd semester Class B Integral Calculus class of Mathematics Education, Bengkulu University, it can be concluded that there is an effect of the implementation of independent learning in integral calculus learning for the subject Riemann Sums on student learning outcomes in Academic Year 2020/2021. This is shown from the results of the t-test obtained $t_{\text {count }}=30,831$ and $t_{\text {table }}=2,042$; because $t_{\text {count }}>$ $t_{\text {table }}, \mathrm{H} 0$ is rejected.

\section{ACKNOWLEDGMENTS}

We thank the 3rd semester undergraduate students of the 2020/2021 Mathematics Education Program of Bengkulu University for their active participation in this study.

\section{REFERENCES}

[1] N.B. Argaheni, Sistematik Review: Dampak Perkuliahan Daring saat Pandemi Covid-19 Terhadap Mahasiswa Indonesia, in: PLACENTUM Jurnal Ilmiah Kesehatan dan Aplikasinya, Vol. 8, No. 2, 2020, pp. 99-108.

[2] Hanifah and N. A. Irsal, N A, The Effectivity of APOS Model Based Worksheets on the Improper Integral, in: Journal of Physics: Conference Series 1317, 2019, pp. 1-12. DOI: 10.1088/1742$6596 / 1317 / 1 / 012115$
[3] Hanifah and N.A. Irsal, Learning Integration Techniques By APOS Model And Analysis Of Student's Error, in: International journal of scientific \& technology research, vol. 8, issue 12 , 2019, pp. 146-153.

[4] Hanifah, Model APOS Pembelajaran Berbantuan Komputer, Bengkulu: CV. Zigie Utama, 2018.

[5] S. Mustagfiroh, Konsep "Merdeka Belajar" Perspektif Aliran Progresivisme John Dewey, in Jurnal Studi Guru dan Pembelajaran, Vol 3, No. 1, 2020, pp. 141-147.

[6] M. Yamin and Syahrir, Pembangunan Pendidikan Merdeka Belajar (Telaah Metode Pembelajaran), in: Jurnal Ilmiah Mandala Education, Vol 6, No.1, 2019, pp. 1-8.

[7] Darhim, Inovasi Pembelajaran PSLV, in: Webinar PPM Universitas Pendidikan Indonesia, 2020.

[8] A. Sadikin and A. Hamidah, Pembelajaran Daring di Tengah Wabah Covid-19, in: BIODIK: Jurnal Ilmiah Pendidikan Biologi, Vol 6, No. 02, 2020 , pp. 214-224. DOI: https://doi.org/10.22437/bio.v6i2.9759

[9] S. Y. H. Sun, Learner perspectives on fully online language learning. Distance Education, 2014, DOI: https://doi.org/10.1080/01587919.2014.891428

[10] R. Pakpahan and Y. Fitriani, Analisa Pemanfaatan Teknologi Informasi Dalam Pembelajaran Jarak Jauh di Tengah Pandemi Virus Corona COVID-19, in: JISAMAR (Journal of Information System, Applied, Management, Accounting and Researh), Vol. 24, No. 2, 2020, pp. 30-36.

[11] Sugiyono, Metode Penelitian Kuantitatif Kualitatif dan R\&D, Bandung: Alfabeta, 2011.

[12] W. Sanjaya, Strategi Pembelajaran Berorientasi Standar Proses Pendidikan, Jakarta: Prenadamedia, 2019.

[13] T. Hartsell and S. Yuen, Video Streaming in Online Learning, in: AACE Journal, Vol. 14, No. 1, 2006, pp. 31-43. 